\title{
A Study on Evaluation Index System of Management Collaborative Efficiency of Power Grid Enterprises
}

\author{
Yong Zhang \\ Department of Corporate Management Consulting, State \\ Grid Energy Research Institute, Beijing, China \\ Email” zhangyong@sgeri.sgcc.com.cn,
}

\begin{abstract}
Management collaborative efficiency of large companies is a difficult problem for enterprises. According to the operational characteristics of power grid enterprises, this paper set up a management collaborative efficiency evaluation index system of power grid enterprises to find out critical problems which reduce the management collaborative efficiency. This paper also put forward some suggestions to improve the efficiency of collaboration.
\end{abstract}

Keywords-Evaluation index system, Management collaborative efficiency, Power grid enterprises

\section{INTRODUCTION}

The important mission of Power grid enterprises is to construct a high quality power grid and operate the power grid continuously and efficiently, which related to the economic growth and energy security of the country. Construction and operation of power grids are composed of the grid assets planning, design, procurement, construction, operation, decommissioning. There is a lot of work, and different departments are involved. Therefore fragmentation problem occurs, departments are always pursuing local or phase-objective optimization. The relatively low

\author{
Jian-Jun Wang* \\ Policy Research Department, China Banking Regulatory \\ Commission, Beijing, China \\ Email: asterwjj@163.com
}

collaborative efficiency has become an urgent management problem for power grid enterprises to solve. According to the operational characteristics of power grid enterprises, this paper set up a management collaborative efficiency evaluation index system of power grid enterprises to find out critical problems which reduce the management collaborative efficiency. This paper also put forward some suggestions to improve the efficiency of collaboration.

\section{EVALUATION INDEX SYSTEM OF MANAGEMENT COLLABORATIVE EFFICIENCY OF POWER GRID ENTERPRISES}

In this paper, we handed out questionnaires to a number of major business departments of several power grid companies. On the basis of statistical analysis of the questionnaire, we interviewed some employees to identify and revise the evaluation dimensions and index of management collaborative efficiency. Finally the evaluation index system of management collaborative efficiency of power grid enterprises was established (see Figure 1). The index system consists of four dimensions, which are seamless process, timely information sharing, whether the decision target is overall optimization and the construction of cooperative mechanisms.

TABLE1. EVALUATION INDEX SYSTEM OF MANAGEMENT COLLABORATIVE EFFICIENCY OF POWER POWER GRID ENTERPRISES

\begin{tabular}{|l|l|}
\hline \multirow{4}{*}{ Process } & Have all the processes been established? \\
\cline { 2 - 3 } Information & Are responsibilities duplication exists? \\
\cline { 2 - 3 } & $\begin{array}{l}\text { Whether the work content to be accomplished and responsible persons are specific on the junctures of } \\
\text { different business processes? }\end{array}$ \\
\hline & Is it clear that what information is required at different working links? \\
\cline { 2 - 3 } & Can the related information be recorded timely and accurately by all processes? \\
\cline { 2 - 3 } & Can the needed information be acquired timely? \\
\cline { 2 - 3 } & Can the departments provide information to the other departments timely? \\
\hline \multirow{4}{*}{ Decision } & $\begin{array}{l}\text { Are the performance assessment objectives towards all departments based on the overall best interests of } \\
\text { the whole enterprise? }\end{array}$ \\
\cline { 2 - 3 } & Whether the overall optimization of this work is the basis of all decision methods? \\
\hline \multirow{5}{*}{ Mechanism } & Have the consultation principles and mechanisms been established? \\
\cline { 2 - 3 } & How about the consultation workload and efficiency? \\
\cline { 2 - 3 } & $\begin{array}{l}\text { When attending a work led by other departments, can the departments fully cooperate with other } \\
\text { departments? }\end{array}$ \\
\cline { 2 - 3 } & Are the mechanisms to ensure the synergy among departments complete? \\
\hline
\end{tabular}




\section{THE EXISTING PROBLEMS IN THE MANAGEMENT COLLABORATION OF GRID ENTERPRISES}

Using the evaluation index system of management collaborative efficiency of power grid enterprises, this paper evaluated the management status of grid companies and found some main problems.

\section{A. Seamless Business Processes Haven't Been Achieved Yet.}

First, it is not clear that which departments should be responsible for some work. Second, some responsibilities are repeated and are vaguely defined in the rules and regulations. For example, several departments all think they should be responsible a piece of work, which bring a lot of communication and coordination problems and reduce the efficiency of management. Third, on the junctures of different business processes, work content and responsibilities are not clear. People don't know who is going to carry out follow-up work, and the content of the work is often missing, which hinder the smooth running of the process.

\section{B. The Information Sharing is Inadequate.}

In some aspects of the work of power grid corporations, there are no fixed information delivery channels and information sharing mechanisms. First, employees at some post don't know exactly what information do they need, therefore their work efficiency is not high. Second, the basis of information work is relatively weak, and some valuable information was not effectively preserved. Third, based on their own interests, a lot of departments will be reluctant to share information with other departments. Inside some departments, full sharing of information can't even be achieved among different divisions, which largely reduces inter-sector collaborative efficiency.

\section{The Optimization of the Enterprises' Overall Benefits can't be Embodied in Some Decision Links.}

First, assessment objectives for each business sector are only based on the optimization of their own departments' business, rather than standing on the perspective of the overall interests of the enterprises. In fact, departments is integral parts of the business, so any work of departments is closely linked with that of any other departments, and even a direct impact on the effectiveness of other departments. Therefore under this goal-oriented, optimization of departments' interests cannot bring the optimization of the overall interests of the enterprises. For example, the assessment target of the device procurement sector is the substantial procurement cost reductions. This target is reasonable for the procurement department itself, but the blind pursuit of the purchasing price reduction is often at the expense of the cost of equipment quality, which in long term will lead to the increase of equipment operation and maintenance costs. Second, there are no uniform requirements on the decision-making basis of department, therefore the decision-making methods aren't based on the optimization of the overall work in some decision links.

\section{Perfect Management Collaboration Mechanisms haven't been Established.}

First, there are no specific principles and mechanisms of consultation. If there are some problems need solving, nobody knows what kind of process should be carried out, which greatly reduces the efficiency of communication. Second, the efficiency of the consultations is low. Standing on the perspectives of their own, the relevant departments do not give in, so the difficulty of communication has been improved. Third, when departments participate in a piece of work which is led by other departments, they always are reluctant to actively cooperate with other departments. Fourth, there aren't enough rules and regulations to achieve the synergy of departments. For example, there are no indexes of department synergy.

\section{SUGGESTIONS ON HOW GRID ENTERPRISES IMPROVE THEIR MANAGEMENT COLLABORATION}

\section{A. Strengthening the Business Processes' Convergence.}

Power grid enterprises should analyze all the businesses and the functions of the departments, and establish clear relationships among departments. First, companies should eliminate the phenomenon of the processes missing and ensure that each job has a clear responsibility department; Second, with regard to the presence of repetitive work responsibilities, enterprises should specify a department solely responsible for the work, or designate a department responsible for the work and the relevant departments participate in; Third, enterprises should focus on the clear responsibilities, job content and job requirements at the processes' intersections. For example, when a power transmission and transformation project is being checked and accepted, construction departments, operation departments, the financial departments should know what work to inspect, what materials to transfer and what information to share.

\section{B. Improve Management Collaborative Efficiency through High Efficient Information Sharing.}

First, enterprises should consolidate the information basis, establish information work standards and unify information coding. Power grid enterprises also should specify the information types and time requirements of information delivery. Second, a unified information sharing platform should be established. Enterprises should formulate clear information sharing responsibilities, jurisdiction and assessment mechanisms. Each department can obtain the required information through a unified platform, and the departments that refuse to share their information will be severely punished. 


\section{Optimize the Overall Interests of the Enterprise as a Decision Target.}

First, a scientific system of sectoral assessment objectives should be established. Enterprises should take full account of the interaction between the relevant businesses, and reasonably adjust department assessment indicators, so that the sectoral objectives and the overall interests of business optimization objectives are coincident. Second, the decision-making methods that pursue the interests of local optimization should be adjusted. Enterprises should make their long-term interests of the overall optimization as a basis for decision making. For example, material procurement department should pursue the lowest cost of assets life cycle, rather than the lowest bid.

\section{Cooperative Mechanisms that Cover All Business Processes should be Established.}

First, enterprises should formulate the consultation principles and mechanisms to deal with disputes, including the main responsibility, disposal authority and the consultation processes. Second, enterprises should set up assessment indicators that allow a department to evaluate the collaborative efficiency of other departments. The lead departments have the rights to evaluate the cooperation level and the participation depth of other departments, so that the collaborative efficiency of departments can be improved.

\section{CONCLUSIONS}

Management collaborative efficiency of large companies is a difficult problem of common concern. This paper has designed an evaluation index system of power grid enterprises management collaborative efficiency. This evaluation index system diagnoses the management collaborative efficiency from processes, information, decision-making and mechanism. In the meantime, based on the overall optimization of the enterprises, this paper put forward some suggestions on management improvement, which has certain significance for large enterprises to improve collaboration efficiency.

\section{REFERENCES}

[1] J. van der Geer, J.A.J. Hanraads, R.A. Lupton, The art of writing a scientific article, J. Sci. Commun. 163 (2000) 51-59.Reference to a book:

[2] W. Strunk Jr., E.B. White, The Elements of Style, third ed., Macmillan, New York, 1979.Reference to a chapter in an edited book:

[3] G.R. Mettam, L.B. Adams, How to prepare an electronic version of your article, in: B.S. Jones, R.Z. Smith (Eds.), Introduction to the Electronic Age, E-Publishing Inc., New York, 1999, pp. 281-304.

[4] R.J. Ong, J.T. Dawley and P.G. Clem: submitted to Journal of Materials Research (2003)

[5] P.G. Clem, M. Rodriguez, J.A. Voigt and C.S. Ashley, U.S. Patent 6,231,666. (2001)

[6] Information on http://www.weld.labs.gov.cn 